\title{
Moral Principles and Political Obligations
}





\section{Moral Principles and Political Obligations}

A. John Simmons

Princeton University Press

Princeton, New Jersey 
Copyright $(\odot 1979$ by Princeton University Press

Published by Princeton University Press, Princeton, New Jersey In the United Kingdom: Princeton University Press, Chichester, West Sussex ALL RIGHTS RESERVED

LIBRARY OF CONGRESS CATALOGING IN PUBLICATION DATA

Simmons, Alan John, 1950-

Moral principles and political obligations.

Bibliography: $p$.

Includes index.

1. Allegiance. 2. Justice. 3. Political ethics.

I. Title

JC328.S55 323.6'5'01 79-2505

ISBN 0-691-07245-0

ISBN 0-691-02019-1 pbk.

This book has been composed in VIP Melior

Princeton University Press books are printed on acid-free paper and meet the guidelines for permanence and durability of the Committee on Production Guidelines for Book Longevity of the Council on Library Resources

Printed in the United States of America by Princeton Academic Press

First Princeton Paperback printing, 1981

$\begin{array}{lllll}9 & 8 & 7 & 6 & 5\end{array}$ 